\title{
Analisis Pengaruh Kinerja Perusahaan Terhadap Loyalitas Konsumen (Studi Kasus: Bengkel Bonti, Bandung)
}

\section{Analysis The Effect Of Company Performance Toward Consumer Loyalty (Case Study: Bengkel Bonti, Bandung)}

\author{
Jimmy Gozaly, Steven Gunawan \\ Program Studi Teknik Industri, Fakultas Teknik, Universitas Kristen Maranatha, Bandung \\ E-mail: jimmy.gozaly@eng.maranatha.edu, stevgun88@gmail.com
}

\begin{abstract}
Abstrak
Bengkel Bonti merupakan sebuah bengkel mobil (body repair) di kota Bandung yang didirikan pada tahun 2009. Pada saat ini perusahaan tengah menghadapi masalah tidak tercapainya target pendapatan sebagaimana yang telah ditetapkan oleh pemilik. Penelitian dilakukan dengan tujuan untuk mengetahui kinerja perusahaan, tingkat loyalitas konsumen, pengaruh kinerja terhadap loyalitas konsumen, proses Segmentation, Targeting, dan Positioning yang tepat, serta memberikan usulan-usulan perbaikan untuk meningkatkan pendapatan.

Pengumpulan data dilakukan melalui kuesioner berdasarkan teori bauran pemasaran (Product, Price, Place, Promotion, Physycal Evidence, People, dan Proces), dengan menggunakan metode purposive sampling. Pengolahan data dilakukan dengan menggunakan metode Multi Regresi Linier dan Importance Performance Analysis (IPA). Hasil pengolahan menunjukkan bahwa terdapat 7 variabel kinerja yang berpengaruh positif terhadap loyalitas, dan 1 variabel kinerja yang berpengaruh secara negatif terhadap loyalitas, dengan nilai kinerja yang belum baik untuk seluruh variabel.

Beberapa usulan perbaikan bagi perusahaan adalah dengan menyediakan beberapa jenis pilihan paket body repair, menyediakan beberapa alternatif proses pembayaran, serta mencari tenaga yang lebih berpengalaman dalam melakukan proses body repair.
\end{abstract}

Kata kunci: Kinerja, Loyalitas, Multi Regresi Liner, Importance Performance Analysis.

\section{Abstract}

Bonti workshop is a car service station (body repair) in Bandung which established in 2009. At this time the company is facing the problem of not achieving the target revenue as set by the owner. The study was conducted with the aim to know the performance of the company, the level of consumer loyalty, the influence of performance on customer loyalty, the right process of Segmentation, Targeting, and Positioning, and provide some suggestions to increase revenue.

The data were collected through questionnaire based on marketing mix theory (Product, Price, Place, Promotion, Physycal Evidence, People, and Proces), using purposive sampling method. Data processing is done by using Linear Multi Regression method and Importance Performance Analysis (IPA). The results showed that there are 7 performance variables that have a positive effect on loyalty, and 1 performance variable that negatively affect the loyalty, with the performance value that has not been good for all variables. Some improvement suggestions for the company are to provide several types of body repair package options, provide several payment alternative process, and seek more experienced personnel in the process of body repair.

Keywords: Performance, Loyalty, Multiple Linier Regression, Importance Performance Analysis. 


\section{Pendahuluan}

Kendaraan bermotor sebagai salah satu sarana transportasi mengalami pertumbuhan yang sangat pesat di Indonesia, khususnya di provinsi Jawa Barat. Hal tersebut secara tidak langsung mendukung berkembangnya bidang usaha jasa pemeliharaan dan perbaikan kendaraan bermotor. Bengkel Bonti sebagai salah satu perusahaan yang bergerak di bidang jasa perbaikan mobil (body repair), berlokasi di kota Bandung dan merintis usaha tersebut sejak tahun 2009. Pada saat ini perusahaan tengah menghadapi masalah tidak tercapainya target pendapatan sebagaimana yang ditetapkan oleh pemilik berdasarkan pengalaman di tahun-tahun sebelumnya. Untuk mengatasi permasalah tersebut dilakukan penelitian yang bertujuan untuk memberikan usulan-usulan perbaikan berdasarkan penilaian konsumen terhadap kinerja perusahaan.

\section{Tinjauan Pustaka 2.1 Kepuasan Konsumen}

Secara umum kepuasan adalah perasaan senang atau kecewa seseorang yang timbul karena membandingkan kinerja yang dipersepsikan produk (atau hasil) terhadap ekspektasi mereka. Jika kinerja gagal memenuhi ekspektasi, pelanggan akan tidak puas. Jika kinerja sesuai dengan ekspektasi, pelanggan akan puas. Jika kinerja melebihi ekspektasi, pelanggan akan sangat puas atau senang (Kotler, 2003).

\subsection{Loyalitas}

Loyalitas konsumen adalah komitmen pelanggan terhadap suatu merek, toko atau pemasok berdasarkan sifat yang sangat positif dalam pembelian jangka panjang (Tjiptono, 2002). Dari pengertian ini dapat diartikan bahwa kesetiaan terhadap merek diperoleh karena adanya kombinasi dari kepuasan dan keluhan. Sedangkan kepuasan pelanggan tersebut hadir dari seberapa besar kinerja perusahaan untuk menimbulkan kepuasan tersebut dengan meminimalkan keluhan sehingga diperoleh pembelian jangka panjang yang dilakukan oleh konsumen. Pelanggan loyal adalah pelanggan yang melakukan pembelian dengan persentase semakin meningkat pada perusahaan tertentu daripada perusahaan lain. Upaya mempertahankan pelanggan harus mendapatkan prioritas yang lebih besar dibandingkan dengam mendapatkan pelanggan baru. Oleh karena itu, loyalitas pelanggan berdasarkan kepuasan murni dan terus-menerus merupakan salah satu aset terbesar yang mungkin didapat oleh perusahaan (Kottler, 2003).

\subsection{Regresi Liniear Berganda}

Analisis regresi linear berganda adalah hubungan secara linear antara dua atau lebih variabel independen $\left(\mathrm{X}_{1}, \mathrm{X}_{2}, \ldots . \mathrm{X}_{\mathrm{n}}\right)$ dengan variabel dependen $(\mathrm{Y})$. Analisis ini digunakan untuk mengetahui arah hubungan antara variabel independen dengan variabel dependen apakah masingmasing variabel independen berhubungan positif atau negatif dan juga untuk memprediksi nilai dari variabel dependen apakah nilai variabel independen mengalami kenaikan atau penurunan. Data yang digunakan biasanya berskala interval atau rasio (Sugiyono, 2013).

Persamaan regresi linear berganda, sebagai berikut:

$\mathbf{Y}=\mathbf{a}+\mathbf{b X}+\mathbf{c X}$

Dimana :

$\mathbf{b}=\frac{n \sum x y-\sum x \sum y}{n \sum x^{2}-\left(\sum x\right)^{2}}$

$\mathbf{a}=\frac{\sum y-b \sum x}{n}$ 
Keterangan :

Y : Variabel Dependen

$\mathrm{X} \quad$ : Variabel Independen

a : Konstanta

b, c : Koefisien regresi (nilai peningkatan atau penurunan)

\subsection{Analisis Tingkat Kepentingan dan Kinerja Pelanggan}

Analisis Tingkat Kepentingan dan Kinerja Pelanggan atau Importance-Performance Analysis (IPA) digunakan untuk menetapkan prioritas perbaikan berdasarkan hasil penilaian terhadap tingkat kepentingan dan kinerja yang dipetakan dalam suatu diagram.

Dalam penelitian ini terdapat 2 buah atribut yang diwakilkan oleh huruf $\mathrm{X}$ dan $\mathrm{Y}$; dimana $\mathrm{X}$ merupakan tingkat kinerja perusahaan, sedangkan Y merupakan tingkat kepentingan pelanggan.

Adapun rumus yang digunakan:

$\mathrm{Tki}=\frac{\mathrm{Xi}}{\mathrm{Yi}} * 100 \%$

dimana:

Tki $=$ Tingkat kesesuaian responden

$\mathrm{Xi}=$ Skor penilaian kinerja perusahaan

$\mathrm{Yi}=$ Skor penilaian kepentingan pelanggan

Perhitungan dilakukan dengan penyederhanaan rumus :

$\overline{\mathrm{X}}=\frac{\sum \mathrm{Xi}}{\mathrm{n}}$ dan $\overline{\mathrm{Y}}=\frac{\sum \mathrm{Yi}}{\mathrm{n}}$

dimana:

$\overline{\mathrm{X}}=$ skor rata-rata tingkat kinerja

$\bar{Y}=$ skor rata-rata tingkat kepentingan

$\mathrm{n}=$ jumlah responden

Diagram kartesius merupakan suatu bangun yang dibagi atas empat bagian yang dibatasi oleh dua buah garis yang berpotongan tegak lurus pada titik-titik $(\overline{\bar{X}}, \overline{\bar{Y}})$, dimana $\overline{\bar{X}}$ merupakan rata-rata dari rata-rata skor tingkat kinerja dari seluruh atribut dan $\overline{\bar{Y}}$ adalah rata-rata dari rata-rata skor dari seluruh atribut.

Rumus:

$\overline{\bar{X}}=\frac{\sum_{i=1}^{N} \overline{X i}}{K}$ dan $\overline{\bar{Y}}=\frac{\sum_{i=1}^{N} \overline{Y i}}{K}$

dimana:

$\mathrm{K}=$ banyaknya atribut

Selanjutnya unsur-unsur tersebut akan dijabarkan dan dibagi menjadi empat bagian ke dalam diagram kartesius ( Gambar 1). 


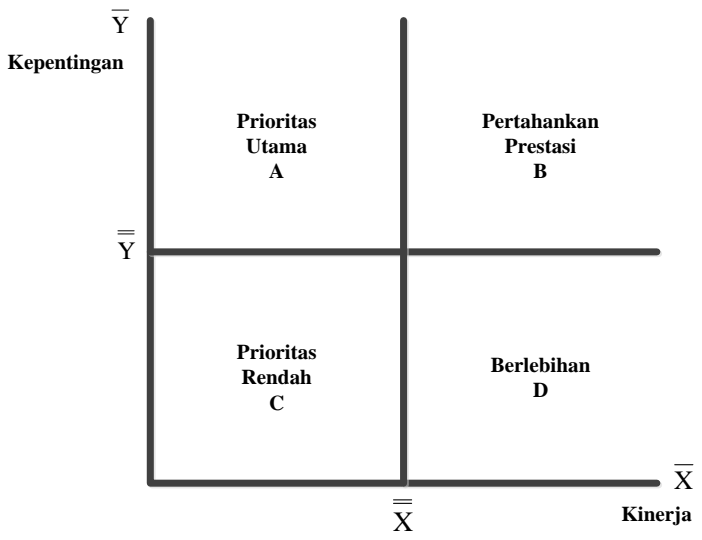

Gambar 1. Diagram Kartesius

\section{Pembahasan}

\subsection{Variabel Penelitian}

Tabel 1. Variabel Penelitian

\begin{tabular}{|c|c|}
\hline No & Variabel \\
\hline \multicolumn{2}{|r|}{ Product } \\
\hline 1 & Keragaman body repair \\
\hline 2 & Fasilitas body repair yang memadai \\
\hline 3 & Kualitas body repair yang diberikan. \\
\hline 4 & Kecepatan dalam proses service \\
\hline \multicolumn{2}{|r|}{ Place } \\
\hline 1 & Letak bengkel yang strategis \\
\hline 2 & Bengkel mudah ditemukan dan terdapat papan penunjuk jalan \\
\hline 3 & Kemudahan dalam hal transportasi (Infrastruktur jalan \& Transportasi umum) \\
\hline \multicolumn{2}{|r|}{ Price } \\
\hline 1 & Harga yang ditawarkan sesuai dengan jasa yang diberikan \\
\hline 2 & Harga yang ditawarkan masuk akal \\
\hline 3 & Diberikan pengurangan harga atau discount \\
\hline \multicolumn{2}{|r|}{ Promotion } \\
\hline 1 & Perusahaan sering melakukan kegiatan iklan \\
\hline 2 & Karyawan/ti memberikan informasi jasa pada konsumen \\
\hline 3 & Kemenarikan promosi \\
\hline \multicolumn{2}{|r|}{ Physical evidence } \\
\hline 1 & Area parkir yang memadai \\
\hline 2 & Kebersihan Bengkel \\
\hline 3 & Sirkulasi udara yang baik \\
\hline 4 & Keamanan dalam bengkel \\
\hline 5 & Area menunggu yang bersih dan nyaman \\
\hline \multicolumn{2}{|r|}{ People } \\
\hline 1 & Keramahan pegawai dalam pelayanan terhadap konsumen \\
\hline 2 & Kecepatan dan ketanggapan pekerja dalam menanggapi keinginan konsumen \\
\hline 3 & Penampilan karyawan/ti yang rapi \\
\hline \multicolumn{2}{|r|}{ Process } \\
\hline 1 & Kemudahan dalam pembayaran \\
\hline 2 & Kemudahan dalam melakukan booking service \\
\hline 3 & Mengerjakan pekerjaan tepat waktu \\
\hline
\end{tabular}


Variabel-variabel penelitian (Tabel 1) disusun berdasarkan model Bauran Pemasaran 7P (Product, Price, Place, Promotion, People, Physical Evidence, dan Process), yang digunakan untuk mengetahui tingkat kepentingan konsumen dan tingkat kinerja perusahaan (menggunakan kuesioner dengan skala Likert), sedangkan pengukuran loyalitas konsumen dilakukan dengan menggunakan variabel Minat untuk datang kembali dan Rekomendasi (menggunakan kuesioner dengan skala Likert).

\subsection{Penentuan Jumlah Sampel Penelitian}

Teknik sampling yang digunakan yaitu non probability sampling dengan metode sampling purposive karena pengambilan anggota sampel dari populasi dengan pertimbangan kriteria tertentu. Dalam penelitian ini yang dijadikan responden adalah konsumen yang pernah menggunakan jasa pebaikan mobil (body repair) di bengkel Bonti.

Jumlah sampel penelitian ditentukan berdasarkan rumus proporsi (Paul D. Leedy) :

$N=\left(\frac{z}{e}\right)^{2}(p)(1-p)$

Dimana :

$\mathrm{N}$ = Ukuran sampel

$\mathrm{Z} \quad=$ standar skor untuk $\alpha$ yang dipilih

$\mathrm{E}=$ tolerable error (kesalahan yang dapat ditolerir)

$1-\alpha=$ tingkat kepercayaan $(95 \%)$

$\alpha \quad=$ tingkat ketelitian $(5 \%)$

$\mathrm{P} \quad=$ proporsi populasi yang akan diteliti. Jika kita tidak dapat memperkirakan proporsi populasi maka diambil kemungkinan terburuk.

$$
\begin{aligned}
N= & \left(\frac{z}{e}\right)^{2}(p)(1-p) \\
& =\left(\frac{z_{0,05 / 2}}{0,11}\right)^{2}(0,5)(1-0,5) \\
& =\left(\frac{1,96}{0,1}\right)^{2}(0,5)(1-0,5) \\
& =96,04 \approx 97 \text { responden }
\end{aligned}
$$

Jumlah sampel minimum adalah 97 responden, pada penelitian digunakan sampel sejumlah 120 responden untuk mengantisipasi adanya pengisian yang tidak memenuhi syarat.

\subsection{Uji Validitas dan Reliabilitas Instrumen Penelitian}

Pengujian validitas tingkat kepentingan dilakukan dengan menggunakan rumus Spearman-Brown (Pearson Product Moment Correlation Coefficient). Nilai koefisien korelasi (r) hasil perhitungan yang lebih besar dari nilai $r$ tabel, menunjukkan bahwa atribut tersebut valid. Pengolahan dilakukan dengan menggunakan perangkat lunak SPSS.

Pengujian reliabilitas digunakan untuk mendapatkan indikasi kestabilan dan konsistensi instrumen untuk mengukur konsep dan membantu penilaian ketepatan pengukuran. Pengujian reliabilitas yang digunakan adalah Inter Item Consistency, menggunakan Cronbach's Alpha $(\alpha)$, dengan nilai rujukan keeratan hubungan sebagai berikut (kriteria Guilford (1956):

1. $\alpha<0.2 \quad$ : Hubungan sangat lemah dan bisa diabaikan

2. $0.2 \leq \alpha<0.4$ : Hubungan lemah (tidak erat)

3. $0.4 \leq \alpha<0.7$ : Hubungan cukup erat

4. $0.7 \leq \alpha<0.9$ : Hubungan erat (reliabel)

5. $0.9 \leq \alpha<1.0$ : Hubungan sangat erat (sangat reliabel)

6. $\alpha=1.00$ : Hubungan yang sempurna 
Tabel 2. Hasil Uji Validitas

\begin{tabular}{|c|c|c|c|c|}
\hline Variabel & No. Instrumen & r-hitung & r-tabel & Keterangan \\
\hline \multirow{27}{*}{ Tingkat Kepentingan } & 1 & 0,633 & 0,187 & Valid \\
\hline & 2 & 0,811 & 0,187 & Valid \\
\hline & 3 & 0,780 & 0,187 & Valid \\
\hline & 4 & 0,747 & 0,187 & Valid \\
\hline & 5 & 0,670 & 0,187 & Valid \\
\hline & 6 & 0,507 & 0,187 & Valid \\
\hline & 7 & 0,584 & 0,187 & Valid \\
\hline & 8 & 0,675 & 0,187 & Valid \\
\hline & 9 & 0,756 & 0,187 & Valid \\
\hline & 10 & 0,682 & 0,187 & Valid \\
\hline & 11 & 0,649 & 0,187 & Valid \\
\hline & 12 & 0,522 & 0,187 & Valid \\
\hline & 13 & 0,661 & 0,187 & Valid \\
\hline & 14 & 0,798 & 0,187 & Valid \\
\hline & 15 & 0,832 & 0,187 & Valid \\
\hline & 16 & 0,706 & 0,187 & Valid \\
\hline & 17 & 0,667 & 0,187 & Valid \\
\hline & 18 & 0,722 & 0,187 & Valid \\
\hline & 19 & 0,622 & 0,187 & Valid \\
\hline & 20 & 0,830 & 0,187 & Valid \\
\hline & 21 & 0,605 & 0,187 & Valid \\
\hline & 22 & 0,563 & 0,187 & Valid \\
\hline & 23 & 0,681 & 0,187 & Valid \\
\hline & 24 & 0,747 & 0,187 & Valid \\
\hline & 25 & 0,747 & 0,187 & Valid \\
\hline & 26 & 0,650 & 0,187 & Valid \\
\hline & 27 & 0,652 & 0,187 & Valid \\
\hline \multirow{27}{*}{ Tingkat Kinerja } & 1 & 0,682 & 0,187 & Valid \\
\hline & 2 & 0,616 & 0,187 & Valid \\
\hline & 3 & 0,721 & 0,187 & Valid \\
\hline & 4 & 0,623 & 0,187 & Valid \\
\hline & 5 & 0,761 & 0,187 & Valid \\
\hline & 6 & 0,623 & 0,187 & Valid \\
\hline & 7 & 0,573 & 0,187 & Valid \\
\hline & 8 & 0,529 & 0,187 & Valid \\
\hline & 9 & 0,579 & 0,187 & Valid \\
\hline & 10 & 0,540 & 0,187 & Valid \\
\hline & 11 & 0,544 & 0,187 & Valid \\
\hline & 12 & 0,439 & 0,187 & Valid \\
\hline & 13 & 0,550 & 0,187 & Valid \\
\hline & 14 & 0,405 & 0,187 & Valid \\
\hline & 15 & 0,580 & 0,187 & Valid \\
\hline & 16 & 0,756 & 0,187 & Valid \\
\hline & 17 & 0,811 & 0,187 & Valid \\
\hline & 18 & 0,790 & 0,187 & Valid \\
\hline & 19 & 0,538 & 0,187 & Valid \\
\hline & 20 & 0,711 & 0,187 & Valid \\
\hline & 21 & 0,690 & 0,187 & Valid \\
\hline & 22 & 0,591 & 0,187 & Valid \\
\hline & 23 & 0,361 & 0,187 & Valid \\
\hline & 24 & 0,437 & 0,187 & Valid \\
\hline & 25 & 0,356 & 0,187 & Valid \\
\hline & 26 & 0,555 & 0,187 & Valid \\
\hline & 27 & 0,604 & 0,187 & Valid \\
\hline \multirow{2}{*}{ Loyalitas } & 1 & 0,951 & 0,187 & Valid \\
\hline & 2 & 0,971 & 0,187 & Valid \\
\hline
\end{tabular}


Berdasarkan hasil perhitungan, seluruh variabel memiliki nilai $r>0.187$ ( $\mathrm{r}$ tabel), sehingga instrumen dinyatakan valid dan data dapat digunakan untuk pengolahan selanjutnya (Tabel 2).

Tabel 3. Hasil Uji Reliabilitas

\begin{tabular}{|c|c|c|c|}
\hline Variabel & $\begin{array}{c}\text { Cronbach's } \\
\text { Alpha }\end{array}$ & Nilai Kritis & Keterangan \\
\hline Tingkat Kepentingan & 0,956 & 0,7 & Reliabel \\
\hline Tingkat Kinerja & 0,928 & 0,7 & Reliabel \\
\hline Loyalitas & 0,902 & 0,7 & Reliabel \\
\hline
\end{tabular}

Hasil perhitungan menunjukkan bahwa seluruh variabel memiliki nilai $\alpha>0,7$, hal tersebut menunjukkan bahwa instrumen memiliki tingkat reliabilitas (konsistensi) yang tinggi (Tabel 3).

\subsection{Multi Regresi Linier}

\subsubsection{Analisis Determinasi}

Tabel 4. Korelasi Ganda

Model Summaryk

\begin{tabular}{|l|r|r|r|r|}
\hline Model & R & R Square & $\begin{array}{c}\text { Adjusted R } \\
\text { Square }\end{array}$ & $\begin{array}{c}\text { Std. Error of } \\
\text { the Estimate }\end{array}$ \\
\hline 1 & $.856^{j}$ & .732 & .711 & .41107 \\
\hline
\end{tabular}

j. Predictors: (Constant), P17, P10, P5, P8, P25, P21, P26, P19

k. Dependent Variable: L

Berdasarkan hasil pengolahan diperoleh angka (R Square) sebesar 0.732. Hal ini menunjukan bahwa persentase pengaruh varibel independen terhadap variabel dependen berdasarkan model penelitan adalah sebesar $72.3 \%$, sedangkan sisanya sebesar $27.7 \%$ dipengaruhi atau dijelaskan oleh variabel -variabel di luar model penelitian (Tabel 4).

\subsubsection{Analisis Korelasi Berganda}

$\mathrm{R}=\sqrt{R^{2}}=\sqrt{0.773}=0.856$

Hasil analisis korelasi ganda dapat dilihat pada output Model Summary dari data analisis regresi linier berganda diatas. Diketahui nilai korelasi berganda yang diperoleh adalah sebesar 0,856 (Tabel 4), dan termasuk dalam kriteria hubungan yang sangat kuat dikarenakan ada pada interval korelasi antara 0,80-1,00. Hal tersebut menunjukan bahwa terdapat hubungan yang sangat kuat antara kinerja (7P) dengan loyalitas konsumen.

\subsubsection{Analisis Uji F}

Rumusan hipotesis simultan yang akan diuji adalah sebagai berikut:

$\mathrm{H}_{0}$ : Koefisien regresi tidak signifikan

$\mathrm{H}_{1}$ : Koefisien regresi signifikan

Taraf signifikansi $(\alpha)$ yang digunakan sebesar $5 \%$.

Kriteria pengambilan keputusan:

Tolak $\mathrm{H}_{0}$ dan terima $\mathrm{H}_{1}$ jika nilai $\mathrm{F}_{\text {hitung }}>\mathrm{F}_{\text {tabel }}$

Terima Ho dan tolak $\mathrm{H}_{1}$ jika nilai $\mathrm{F}_{\text {hitung }}<\mathrm{F}_{\text {tabel }}$ 
Tabel 5. Anova

ANOVA $^{\text {a }}$

\begin{tabular}{|l|r|r|r|r|r|}
\hline Model & \multicolumn{1}{|c|}{$\begin{array}{c}\text { Sum of } \\
\text { Squares }\end{array}$} & df & Mean Square & \multicolumn{1}{c|}{ F } & Sig. \\
\hline 1 & 46.651 & 8 & 5.831 & 34.509 & $.000^{\mathrm{k}}$ \\
& 17.067 & 101 & .169 & & \\
& 63.718 & 109 & & & \\
\hline
\end{tabular}

a. Dependent Variable: $L$

k. Predictors: (Constant), P17, P10, P5, P8, P25, P21, P26, P19

Nilai statistik $\mathrm{F}_{\text {hitung }}$ diperoleh dari tabel distribusi $F$ pada taraf signifikansi sebesar 5\% dengan jumlah variabel independen $\left(d f_{1}\right) 27$ dan $d f_{2}$ (n-k-1) sebesar 82 diperoleh nilai $\mathrm{F}_{\text {tabel }}$ sebesar 1.477. Pada tabel diatas dapat, diketahui bahwa nilai $F_{\text {hitung }}$ yang diperoleh adalah sebesar 34.509 dan lebih besar dari $1.477\left(\mathrm{~F}_{\text {tabel }}\right)$, sehingga keputusan pengujian hipotesis simultan adalah menolak $\mathrm{H}_{0}$ dan menerima $\mathrm{H}_{1}$. Dari nilai signifikansi juga dapat dilihat bahwa nilai Sig. sebesar 0,000 lebih kecil dari $0,05(\alpha)$. Hasil tersebut menujukan bahwa kinerja berpengaruh signifikan terhadap loyalitas konsumen (Tabel 5).

\subsubsection{Analisis Uji T}

Tabel 6. Variabel Yang Berpengaruh

Coefficients $^{a}$

\begin{tabular}{|c|c|c|c|c|c|c|c|c|}
\hline \multirow{2}{*}{\multicolumn{2}{|c|}{ Model }} & \multicolumn{2}{|c|}{ Unstandardized Coefficients } & \multirow{2}{*}{$\begin{array}{c}\begin{array}{c}\text { Standardized } \\
\text { Coefficients }\end{array} \\
\text { Beta }\end{array}$} & \multirow[b]{2}{*}{$\mathrm{t}$} & \multirow[b]{2}{*}{ Sig. } & \multicolumn{2}{|c|}{$95.0 \%$ Confidence Interval for B } \\
\hline & & $\mathrm{B}$ & Std. Error & & & & Lower Bound & Upper Bound \\
\hline \multirow[t]{6}{*}{1} & (Constant) & -.930 & .263 & & -3.537 & .001 & -1.452 & -.409 \\
\hline & P10 & .252 & .061 & .239 & 4.140 & .000 & .131 & .373 \\
\hline & P5 & .309 & .081 & .260 & 3.814 & .000 & .148 & .470 \\
\hline & $\mathrm{P} 21$ & -.303 & .084 & -.264 & -3.597 & .000 & -.471 & -.136 \\
\hline & P26 & .196 & .059 & .202 & 3.308 & .001 & .079 & .314 \\
\hline & P19 & .173 & .073 & .151 & 2.364 & .020 & .028 & .318 \\
\hline
\end{tabular}

a. Dependent Variable: L

Hipotesis yang digunakan :

$\mathrm{H}_{0}$ : variabel kinerja tidak mempengaruhi loyalitas konsumen.

$\mathrm{H}_{1}$ : variabel kinerja mempengaruhi loyalitas konsumen.

Nilai t tabel $\mathrm{t}$ tabel $= \pm 1.982($ signifikansi $5 \%)$

Berdasarkan hasil pengolahan variabel-variabel kinerja dengan nilai t hitung $>\mathrm{t}$ tabel atau dengan nilai Sig lebih kecil $(<)$ dari 0.025 dinyatakan berpengaruh secara signifikan terhadap variabel dependen . Adapun variabel-variabel tersebut adalah : P12 (kebersihan bengkel), P10 (harga yang ditawarkan sesuai dengan jasa yang diberikan), P5 (kecepatan dalam proses body repair), P8 (kemudahan dalam menemukan lokasi bengkel), P25 (kerapihan karyawan), P21 (fasilitas makanan dan minuman pada ruang tunggu), P26 ( kemudahan dalam pembayaran), dan P19 (kebersihan toilet) (Tabel 6).

Diperoleh model regresi :

$\mathrm{Y}=-0.930+0.357 \mathrm{P} 17+0.252 \mathrm{P} 10+0.309 \mathrm{P} 5+0.249 \mathrm{P} 8+0.220 \mathrm{P} 25-0.303 \mathrm{P} 21+0.196 \mathrm{P} 26$ $+0.173 \mathrm{P} 19$ 
Keterangan :

$\begin{array}{ll}\mathrm{Y} & =\text { Loyalitas } \\ \mathrm{P} & =\text { Kinerja (bauran pemasaran) }\end{array}$

\subsection{Importance Performance Analysis (IPA)}

Pengolahan data dengan metode Importance Performance Analysis (IPA) dilakukan untuk mengetahui posisi setiap atribut penelitian berdasarkan nilai tingkat kepentingan dan tingkat kinerja yang dipetakan dalam diagram kartesius (Gambar 2), berdasarkan penilaian yang dilakukan oleh konsumen terhadap Bengkel Bonti (Tabel 7).

Tabel 7. Data Tingkat Kepentingan dan Kinerja

\begin{tabular}{|c|l|c|c|}
\hline No. & \multicolumn{1}{|c|}{ Pertanyaan } & Kepentingan & Performansi \\
\hline 1 & Kelengkapan jenis body repair yang ditawarkan lengkap (las ketok, painting, dII) & 2.92 & 2.92 \\
\hline 2 & Kelengkapan alat-alat yang digunakan untuk melakukan body repair & 2.91 & 2.66 \\
\hline 3 & Kemoderenan perlatan yang digunakan untuk body repair & 2.89 & 2.65 \\
\hline 4 & Kualitas body repair & 2.89 & 2.71 \\
\hline 5 & Kecepatan dalam proses body repair & 2.92 & 2.65 \\
\hline 6 & Ketepatan waktu pengerjaan sesuai yang dijanjikan & 2.93 & 2.52 \\
\hline 7 & Letak bengkal Bonti di tengah kota & 2.91 & 2.75 \\
\hline 8 & Kemudahan dalam menemukan lokasi bengkel bonti & 2.84 & 2.71 \\
\hline 9 & Kemudahan dalam hal transportasi (dekat dengan jalan raya dan transportasi umum) & 2.83 & 2.74 \\
\hline 10 & Harga yang ditawarkan sesuai dengan kualitas jasa yang diberikan & 2.93 & 2.56 \\
\hline 11 & Frekuensi pemberian diskon & 2.90 & 2.22 \\
\hline 12 & Jumlah diskon yang diberikan & 2.91 & 2.44 \\
\hline 13 & Melakukan promosi menggunakan media sosial & 2.92 & 2.70 \\
\hline 14 & Kemenarikan bentuk promosi yang dilakukan & 2.89 & 2.68 \\
\hline 15 & Kemampuan karyawan dalam memberikan informasi jasa yang ditawarkan & 2.83 & 2.71 \\
\hline 16 & Area parkir yang memadai & 2.89 & 2.71 \\
\hline 17 & Kebersihan bengkel & 2.91 & 2.75 \\
\hline 18 & Sirkulasi udara diruang tunggu & 2.92 & 2.87 \\
\hline 19 & Kebersihan toilet & 2.89 & 2.35 \\
\hline 20 & Keamanan dalam bengkel terhadap risiko kehilangan & 2.89 & 2.70 \\
\hline 21 & Fasilitas makanan dan minuman pada ruang menunggu & 2.91 & 2.67 \\
\hline 22 & Fasilitas hiburan yang terdapat pada ruang menunggu (Wifi, Tv, dil) & 2.91 & 2.27 \\
\hline 23 & Keramahan karyawan dalam melayani konsumen & 2.89 & 2.81 \\
\hline 24 & Ketanggapan karyawan dalam menanggapi keluhan konsumen & 2.82 & 2.75 \\
\hline 25 & Kerapihan karyawan & 2.82 & 2.67 \\
\hline 26 & Kemudahan dalam pembayaran (Tunai, debit dan kredit) & 2.89 & 2.53 \\
\hline 27 & Kemudahan melakukan booking service & 2.93 & 2.46 \\
\hline Rata-Rat Skor Tanggapan & $\mathbf{2 . 8 9}$ & $\mathbf{2 . 6 4}$ \\
\hline
\end{tabular}




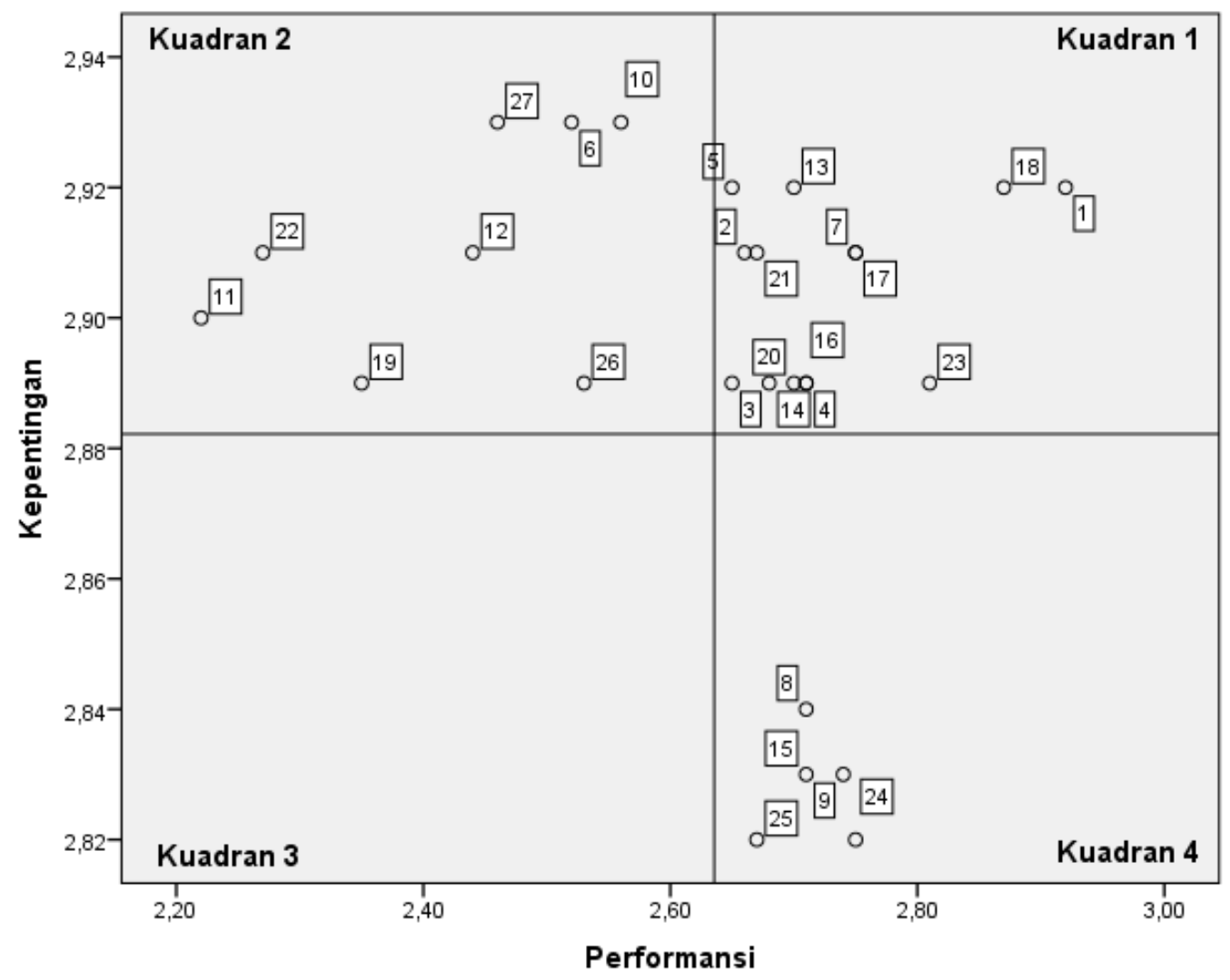

Gambar 2. Diagram IPA

Berdasarkan diagram Importance Performance Analysis, dapat diketahui posisi setiap atribut pada masing-masing kuadran, yaitu :

\section{Kuadran 1}

1) Kelengkapan jenis body repair yang ditawarkan (las ketok, painting, dll).

2) Kelengkapan alat-alat yang digunakan untuk melakukan body repair.

3) Kemoderenan perlatan yang digunakan untuk body repair.

4) Kualitas body repair.

5) Kecepatan dalam proses body repair.

7) Letak bengkal Bonti di tengah kota.

13) Melakukan promosi menggunakan media sosial.

14) Kemenarikan bentuk promosi yang dilakukan.

16) Area parkir yang memadai.

17) Kebersihan bengkel.

18) Sirkulasi udara diruang tunggu.

20) Keamanan dalam bengkel terhadap risiko kehilangan.

21) Fasilitas makanan dan minuman pada ruang menunggu.

23) Keramahan karyawan dalam melayani konsumen.

Pada kuadran 1 terdapat 14 atribut yang dianggap cukup penting dengan kinerja yang cukup baik, namun perusahaan tetap perlu melakukan perbaikan terhadap atribut-atribut tersebut karena belum dinilai baik oleh konsumen.

\section{Kuadran 2}

6) Ketepatan waktu pengerjaan sesuai yang dijanjikan.

10) Harga yang ditawarkan sesuai dengan kualitas jasa yang diberikan.

11) Frekuensi pemberian diskon.

12) Jumlah diskon yang diberikan. 
19) Kebersihan toilet.

22) Fasilitas hiburan yang terdapat pada ruang menunggu (Wifi, TV, dll).

26) Kemudahan dalam pembayaran (Tunai, debit dan kredit).

27) Kemudahan melakukan booking service.

Pada kuadran 2 terdapat 8 atribut yang dianggap cukup penting dengan kinerja yang kurang baik, sehingga perusahaan perlu menjadikan atribut-atribut tersebut sebagai prioritas perbaikan.

\section{Kuadran 3}

Tidak terdapat atribut yang masuk ke dalam kuadran 3, sehingga analisis tidak dilakukan.

\section{Kuadran 4}

8) Kemudahan dalam menemukan lokasi Bengkel Bonti.

9) Kemudahan dalam transportasi (dekat dengan jalan raya dan transportasi umum).

15) Kemampuan karyawan dalam memberikan informasi jasa.

24) Ketanggapan karyawan dalam menanggapi keluhan konsumen.

25) Kerapihan karyawan.

Pada kuadran 4 terdapat 5 atribut yang dianggap tidak terlalu penting dengan kinerja yang cukup baik, namun perusahaan tetap perlu melakukan perbaikan terhadap atribut-atribut tersebut karena belum dinilai baik oleh konsumen.

\subsection{Target Pasar}

Berdasarkan hasil segmentasi profil responden, ditentukan target pasar yang dituju, dengan memilih segmen potensial, dengan hasil sebagai berikut (Tabel 8) :

Tabel 8. Segmentasi dan Targeting

\begin{tabular}{|c|c|c|}
\hline No & Jenis Segmentasi & Targeting \\
\hline 1 & Jenis Kelamin & Pria dan Wanita \\
\hline 2 & Usia & 23 - 40 tahun \\
\hline 3 & Wilayah Tempat Tinggal & Bandung barat, Bandung selatan, dan Jakarta \\
\hline 4 & Pekerjaan & Wiraswasta, Mahasiswa, dan Supir \\
\hline 5 & Penghasilan yang Didapatkan & $>$ Rp 2.000.000 \\
\hline 6 & Sumber Informasi & Teman \\
\hline 7 & Frekuensi Kedatangan & Bila terjadi kerusakan mobil \\
\hline 8 & Faktor yang Diutamakan & Kualitas \\
\hline
\end{tabular}

\subsection{Positioning}

Berdasarkan hasil penilaian konsumen terhadap bengkel Bonti dan target pasar yang dituju, maka perusahaan sebaiknya memposisikan diri sebagai salah satu bengkel mobil (body repair) dengan kelengkapan jenis paket perbaikan yang ditawarkan disertai keramahan pelayanan karyawan. Image yang dapat ditanamkan bengkel Bonti kepada konsumen adalah "Lengkap peralatannya, lengkap pula pelayanannya".

\subsection{Analisis Gabungan}

Prioritas perbaikan ditentukan berdasarkan penggabungan hasil pengolahan data dengan metode multi regresi linier dan IPA (Tabel 9), dengan fokus perbaikan pada atribut-atribut yang langsung berpengaruh terhadap loyalitas (masuk dalam persamaan regresi) dan secara berurutan berada pada kuadran II, I, dan IV. Dengan demikian variabel-variabel yang menjadi prioritas perusahaan untuk ditingkatkan (seluruh nilai kinerja di bawah 3) adalah variabel 10, 26, 19, 17, 5, 21, 8, dan 25. Sedangkan untuk variabel-variabel lainnya dapat ditingkatkan kemudian, mengingat cukup 
dipentingkan (nilai kepentingan mendekati 3) dan belum dinilai baik oleh konsumen (nilai kinerja di bawah 3).

Tabel 9. Analisis Gabungan

\begin{tabular}{|c|c|c|c|c|c|}
\hline Variabel & Nama Variabel & $\begin{array}{c}\text { Uji Regresi } \\
\text { (ada/tidaknya } \\
\text { pengaruh) }\end{array}$ & $\begin{array}{c}\text { Uji IPA } \\
\text { (Kuadran } \\
\text { I/II/III/IV) }\end{array}$ & $\begin{array}{c}\text { Koefisien } \\
\text { persamaan } \\
\text { regresi }\end{array}$ & $\begin{array}{c}\text { Prioritas } \\
\text { Usulan }\end{array}$ \\
\hline 10 & Harga yang ditawarkan sesuai dengan kualitas jasa yang diberikan & Ada & Kuadran II & 0.252 & 1 \\
\hline 26 & Kemudahan dalam pembayaran (Tunai, debit dan kredit) & Ada & Kuadran II & 0.196 & 2 \\
\hline 19 & Kebersihan toilet & Ada & Kuadran II & 0.173 & 3 \\
\hline 17 & Kebersihan bengkel & Ada & Kuadran I & 0.357 & 4 \\
\hline 5 & Kecepatan dalam proses body repair & Ada & Kuadran I & 0.309 & 5 \\
\hline 21 & Fasilitas makanan dan minuman pada ruang menunggu & Ada & Kuadran I & -0.303 & 6 \\
\hline 8 & Kemudahan dalam menemukan lokasi bengkel bonti & Ada & Kuadran IV & 0.249 & 7 \\
\hline 25 & Kerapihan karyawan & Ada & Kuadran IV & 0.22 & 8 \\
\hline 6 & Ketepatan waktu pengerjaan sesuai yang dijanjikan & Tidak Ada & Kuadran II & & 9 \\
\hline 11 & Frekuensi pemberian diskon & Tidak Ada & Kuadran II & & 10 \\
\hline 12 & Jumlah diskon yang diberikan & Tidak Ada & Kuadran II & & 11 \\
\hline 22 & Fasilitas hiburan yang terdapat pada ruang menunggu (Wifi, Tv, dII) & Tidak Ada & Kuadran II & & 12 \\
\hline 27 & Kemudahan melakukan booking service & Tidak Ada & Kuadran II & & 13 \\
\hline 1 & Kelengkapan jenis body repair yang ditawarkan lengkap (las ketok, painting, dII) & Tidak Ada & Kuadran I & & 14 \\
\hline 2 & Kelengkapan alat-alat yang digunakan untuk melakukan body repair & Tidak Ada & Kuadran I & & 15 \\
\hline 3 & Kemoderenan perlatan yang digunakan untuk body repair & Tidak Ada & Kuadran I & & 16 \\
\hline 4 & Kualitas body repair & Tidak Ada & Kuadran I & & 17 \\
\hline 7 & Letak bengkal Bonti di tengah kota & Tidak Ada & Kuadran I & & 18 \\
\hline 13 & Melakukan promosi menggunakan media sosial & Tidak Ada & Kuadran I & & 19 \\
\hline 14 & Kemenarikan bentuk promosi yang dilakukan & Tidak Ada & Kuadran I & & 20 \\
\hline 16 & Area parkir yang memadai & Tidak Ada & Kuadran I & & 21 \\
\hline 18 & Sirkulasi udara diruang tunggu & Tidak Ada & Kuadran I & & 22 \\
\hline 20 & Keamanan dalam bengkel terhadap risiko kehilangan & Tidak Ada & Kuadran I & & 23 \\
\hline 23 & Keramahan karyawan dalam melayani konsumen & Tidak Ada & Kuadran I & & 24 \\
\hline 9 & Kemudahan dalam hal transportasi (dekat dengan jalan raya dan transportasi umum) & Tidak Ada & Kuadran IV & & 25 \\
\hline 15 & Kemampuan karyawan dalam memberikan informasi jasa yang ditawarkan & Tidak Ada & Kuadran IV & & 26 \\
\hline 24 & Ketanggapan karyawan dalam menanggapi keluhan konsumen & Tidak Ada & Kuadran IV & & 27 \\
\hline
\end{tabular}

\section{Kesimpulan dan Saran 4.1 Kesimpulan}

Beberapa usulan strategi pemasaran (prioritas) yang dapat diberikan kepada pihak manajemen bengkel Bonti guna meningkatkan pencapaian target perusahaan adalah :

- Menyediakan beberapa pilihan paket perbaikan, misalnya menggunakan cat dengan kualitas biasa atau premium, sehingga konsumen dapat menyesuaikan anggaran yang dimiliki dengan kualitas hasil perbaikan.

- Menyediakan fasilitas pembayaran dengan kartu debit dan kartu kredit.

- Melakukan pembersihan toilet secara terjadwal.

- Menugaskan karyawan yang secara khusus bertanggung jawab atas kebersihan fasilitas bengkel dan lingkungannya.

- Memberikan pengarahan kepada pekerja untuk selalu membereskan setiap peralatan yang telah digunakan dan menyimpannya di tempat yang telah disediakan.

- Memperbaiki sistem kerja yang digunakan, guna meningkatkan waktu pengerjaan perbaikan dengan menggunakan prosedur standar operasi.

- Mencari pekerja yang berpengalaman dalam bidang body repair sehingga mampu melakukan perbaikan dengan baik dan cepat. 
- Membuat papan nama bengkel Bonti dengan ukuran besar dan warna kontras, agar lebih mudah ditemukan oleh konsumen.

- Memberikan seragam untuk pekerja agar terlihat rapih dalam bekerja.

\subsection{Saran}

Sebaiknya bengkel Bonti juga melakukan penelitian terhadap tingkat persaingan dengan bengkelbengkel sejenis di sekitarnya..

\section{Daftar Pustaka}

Azwar (2000), “Reliabilitas dan Validitas”, Pustaka Pelajar Offset, Yogyakarta.

Ghozali, I. (2009), “Aplikasi Analisis Multivariate dengan Program SPSS”, Badan Penerbit UNDIP, Semarang.

Ghozali, I. (2011), “Aplikasi Analisis Multivariate dengan Program IBM SPSS 19 (5 ed.)”, Badan Penerbit Universitas Diponegoro, Semarang.

Hurriyati, R. (2005), “Bauran Pemasaran dan Loyalitas Konsumen”, CV. Alfabeta, Bandung.

Kotler, Philip A., et.al. (2003), "Marketing Management: An Asian Perspective”, $3^{\text {rd }}$ edition, Prentice-Hall, Singapore.

Sugiyono, (2013), "Metode Penelitian Bisnis (Pendekatan Kuantitatif, Kualitatif, dan R\&D", Alfabeta, Bandung.

Tjiptono, F. (2002), "Strategi Pemasaran", Andi, Yogyakarta.

Walpole, R. E. (1995), “Pengantar Statistika”, Edisi 3, PT Gramedia Pustaka Utama, Jakarta. 